\title{
18-Millî kimliğin inşasında geleneğin rolü: Mustafa Kutlu örneği
}

\section{Merve AVCI1}

\section{Ali Fuat ARICI²}

APA: Avcı, M.; Arıcı, A. F. (2020). Millî kimliğin inşasında geleneğin rolü: Mustafa Kutlu örneği. RumeliDE Dil ve Edebiyat Araştırmaları Dergisi, (21), 305-321. DOI: 10.29000/rumelide.841096.

\section{$\ddot{\mathbf{O} z}$}

Millî kimlik, küreselleşen dünyada millî olma özelliğini korumak isteyen toplumlar için önem arz etmektedir. Küreselleşen dünyada teknolojik gelişmelerin de etkisiyle millı̂ kimlikler zarar görmektedir. Millî kimliğin korunması, milletin değerlerine sahip çıkması ile mümkündür. İşte bu değerlerden biri olan gelenekler, ülkemizin her yerinde aynı inanç ve kültür değerleri üzerinde şekillendiği için bizi "biz” yapmaktadır. Gelenekler, bir milletin geçmişten bugüne kadar getirdiği, günlük hayatındaki uygulama, inanç ve âdetleri kapsamaktadır. Türk millî kimliğinin millete aktarılmasında kullanılabilecek önemli araçlardan biri edebî metinlerdir. Günümüz edebiyatında yaşayan önemli hikâyecilerimizden biri olan Mustafa Kutlu, ülkemizin modernleşme sürecinin başlamasına tanık olmuş ve Türkiye'nin modernleşme sürecinin getirdiklerini eserlerine taşımış bir yazardır. Çalışmanın amacı, Türkiye'nin modernleşme sürecine ömrü boyunca tanıklık etmiş yazar Mustafa Kutlu'nun 2000-2018 yılları arasında yayımlanan hikâyelerindeki geleneksel unsurları tespit ederek eserlerde geleneksel unsurlara nasıl yer verdiğini ve bu unsurların milli kimlikle ilişkisini ortaya koymaktır. 1960’lı yılların sonundan beri hikâye yazan ve edebiyatımızın yaşayan büyük hikâyecilerinden biri olarak görülen Mustafa Kutlu'nun eserlerinin bu çalışmada incelenmesinin nedeni, hikâyelerini Şark-İslâm kültürü ile beslemesidir. Modernizmin karşısına gelenekleri koyan Kutlu, modernizmin millî kimliğe verdiği zararı engellemenin yolu olarak geleneklere tutunulması gerektiğini eserlerindeki kahramanlarıyla okuyucuya yansıtmaktadır. Mustafa Kutlu'nun 2000-2018 yılları arasında yayımlanan hikâyelerinde en çok yer alan gelenekler, evlenme geçiş dönemi etrafında gelişen geleneklerdir. Mustafa Kutlu'nun 2000-2018 yılları arasında yayımlanan hikâyelerinde en az rastlanan geleneksel unsur, canlı varlıklar ile ilgili inanışlardır. Mustafa Kutlu'nun incelenen eserlerinin geleneksel ögelere sıkça yer vermesi nedeniyle toplumsal bağı artırdı̆̆ı, millî kimliğin topluma hatırlatılmasında nitelikli eserler olduğu tespit edilmiştir.

Anahtar kelimeler: Millî kimlik, gelenek, Mustafa Kutlu, Türk dili ve edebiyatı, Türkçe

\section{The role of tradition to construct of the national identity the example of Mustafa Kutlu}

\begin{abstract}
National identity is important for societies that want to maintain their nationality in the globalizing world. In the globalizing world, national identities suffer with the effect of technological
\end{abstract}

YL Öğrencisi, Yıldız Teknik Üniversitesi, Sosyal Bilimler Enstitüsü,Türkçe ve Sosyal Bilimler Eğitimi Bölümü, Türkçe Eğitimi ABD (İstanbul, Türkiye), mervecizmecioglu@gmail.com, ORCID ID: oooo-0002-5107-8057 [Araştırma makalesi, Makale kaytt tarihi: 25.09.2020-kabul tarihi: 20.12.2020; DOI: 10.29000/rumelide.841096] Prof. Dr., Yıldız Teknik Üniversitesi, Eğitim Fakültesi, Sosyal Bilimler ve Türkçe Eğitimi Bölümü, Türkçe Eğitimi ABD (İstanbul, Türkiye), afaturkey@hotmail.com ORCID ID: 0000-0003-0980-0824

Adres Address

İstanbul Medeniyet Üniversitesi, Eğitim Bilimleri Fakültesi, Türkçe $\quad$ İstanbul Medeniyet University, Faculty of Education Sciences, ve Sosyal Bilimler Eğitimi Bölümü, Türkçe Eğitimi ABD Cevizli Turkish and Social Scinces Education, Turkish Language Teaching Kampüsü, Kartal-IstanbulTÜ e-posta: editor@rumelide.com Education, Cevizli Campus, Kartal-İstanbul /TURKEY e-mail: editor@rumelide.com 
developments. The protection of national identity is only possible by protecting the values of the nation. Traditions, which are one of these values, make us "we" because they are shaped on the same belief and cultural values all over our country. Traditions include the practices, beliefs and customs of a nation from the past to the present. Literary texts are one of the important tools that can be used in transferring Turkish national identity to the nation. One of our most important storyteller living in today's literature, Mustafa Kutlu, witnessed the beginning of our country's modernization process and Turkey's modernization process is a writer who has possession of the artifacts they brought. The aim of the study is that Turkey has witnessed over the life of the modernization process writer Mustafa Kutlu in works by identifying traditional elements in stories published between the years 2000-2018 is given how the place with traditional elements and reveal the relationship between national identity of these elements. The reason why the works of Mustafa Kutlu, who has written a story since the end of the 1960 s and who is seen as one of the great living storytellers of our literature, are examined in this study is that he feeds his stories with the culture of East-Islam. Putting traditions against modernism, Kutlu reflects to the reader with the heroes in his works that tradition should be held as a way to prevent the damage caused by modernism to national identity. The most prominent traditions in Mustafa Kutlu's stories published between 2000 and 2018 are those that developed around the transition period of marriage. The least common traditional element in Mustafa Kutlu's stories published between 2000 and 2018 is beliefs about living beings. It has been determined that the works of Mustafa Kutlu have increased the social bond due to the frequent use of traditional elements and are qualified works in reminding the society of national identity.

Keywords: National identity, tradition, Mustafa Kutlu, Turkish language and literature, Turkish

\section{Giriş}

Gelenekler, bir milletin geçmişten bugüne kadar getirdiği, günlük hayatındaki uygulama, inanç ve âdetleri kapsamaktadır. Bir milletin fertleri, atalarından yadigâr kalan gelenekleri sayesinde geçmişle bağlantı kurabilmekte, milletini millet yapan bağlarına daha sıkı sarılabilmektedir. Millî kimlik, küreselleşen dünyada millî olma özelliğini korumak isteyen toplumlar için önem arz etmektedir. Millî kimliğin korunması, milletin değerlerine sahip çıkması ile mümkündür. Geleneksel toplumlarda gelenek-göreneklerle var olan fakat o toplumlarda sorun olarak görülmeyen kimlik, sosyal ve kültürel değişmelerle birlikte bir sorun hâline gelmiştir (Güvenç 2005: 5). Kimlik kavramının bir sorun hâline gelmesinde ise küreselleşmenin payı büyüktür. Küreselleşme, insanlı̆̆ın bütünleşerek ve homojenleşerek tek dünya toplumu hâline geleceği, bu dünya toplumunun tek siyasi merkezde örgütleneceği ve buna bağlı olarak insanların ayrı milletlere bağlı milliyetçilikler yerine dünya milliyetçiliği yapmaları gerektiği iddiası üzerine kurgulanmıştır (Atasoy 2009: 827). Küreselleşmenin karşısındaki en büyük tehdit ise millî kimliklerdir. Millî kimlik, "aynı kültür çevresinde yaşayıp, aynı mukaddesleri paylaşan ve benzer dış şartlar içinde yaşayanları aynı şahsiyet içinde birleştiren bir kavramdır" (Kösoğlu 2018: 37). Bu yüzden küreselleşme, millî kimliklere zarar vererek karşısındaki tehdidi kaldırmak ister. Küreselleşme karşısında yok olma tehlikesiyle karşı karşıya kalan milletler, kendilerini korumak için millî kimliklerini oluşturan değerlerini kalkan olarak kullanmıştır. Millî kimlikleri oluşturan değerlerin başında ise dil ve kültür gelmektedir. Gelecek kuşaklara miras olarak bırakabileceğimiz dilimiz ve edebiyatımız gibi kültür varlıklarımızı işleyip bunlar üzerine eser ortaya koyan sanatkârlarımız sayesinde bu birikimimiz bir taraftan gelişip ilerlerken diğer taraftan kaybolmaktan kurtularak gelecek nesillere aktarılma imkânı bulmaktadır (Arıcı 2019: 69). Edebî metinlerin en önemli etkilerinden biri de okuyucunun kimliğini ve şahsiyetini şekillendirip

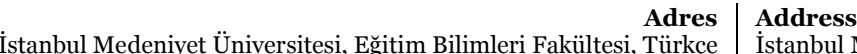
ve Sosyal Bilimler Ĕ̈itimi Bölümü, Türkçe Ĕ̆ Turkish and Social Scinces Education, Turkish Language Teaching Kampüsü, Kartal-İstanbul/TÜRKIYE $\quad$ Education, Cevizli Campus, Kartal-İstanbul /TURKEY e-posta: editor@rumelide.com 1 e-mail: editor@rumelide.com
} 
yoğurmasıdır. Onların bu işlevini bilen kimi devletler durumu kendi anlayışlarına uygun yapıda insan yetiştirmede kullanmıştır. Yetiştirilen bu insan tipi de onlar tarafından "ideal tip" olarak görülmüştür (Eflatun 2019: 149). Bu nedenle de Türk kültür anlayışına uygun metinler seçilerek Türk kültür anlayışına uygun yapıda insan yetiştirilmesi sağlanmalıdır. Bu bağlamda Mustafa Kutlu hikâyeleri bu çalışmada ele alınmıştır. Bu çalışmada Mustafa Kutlu hikâyelerinin seçilmesinin ise çeşitli nedenleri vardır. Mustafa Kutlu, modern insanın çıkmazlarına, sosyal ve iktisadi değişimin insanlarda açtı̆̆ı buhranlara karşı, içinde olmaktan mutlu olduğu dünya görüşünün değerlerini, dünyayı algılayış tarzlarını, gelenek-görenek ve âdetlerini, unutulmuş bir hazineye benzeyen bu değerleri, farklı bir formda üreterek metinler arası ve tasavvufi göndermelerle yeniden inşa etmektedir. Bu yöntem onun hikâyelerini zengin bir kaynak hâline getirmektedir (Anar 2012: 333). Bu çalışmada Mustafa Kutlu'nun yirmi hikâye kitabı inceleme nesnesi olarak belirlenmiştir. Bu hikâyeler: Uzun Hikâye, Beyhude Ömrüm, Mavi Kuş, Tufandan Önce, Rüzgârlı Pazar, Chef, Menekşeli Mektup, Kapıları Açmak, Huzursuz Bacak, Tahir Sami Bey’in Özel Hayatı, Zafer Yahut Hiç, Hayat Güzeldir, Anadolu Yakası, Siradışı Bir Ödül Töreni, Nur, Tìrende Bir Keman, Hesap Günü, İyiler Ölmez, Tarla Kuşunun Sesi, Sevincini Bulmak'tır. Bu eserler içerisinde Hayat Güzeldir eseri dışında kalan hikâyeler uzun hikâye olarak nitelendirilmektedir. Bu araştırmada Mustafa Kutlu'nun 2000 sonrasında yayımlanan 20 hikâyesi nitel araştırma yöntemlerinden doküman taraması ile incelenmiştir. Mustafa Kutlu'nun 2000 sonrası hikâyelerinde geleneksel unsurların belirlenmesi ve sınıflandırılması için Sedat Veyis Örnek'in (2018) "Türk Halkbilimi" ve Pertev Naili Boratav'ın (2016) "10o Soruda Türk Folkloru" adlı eserlerindeki tasnifler de göz önünde bulundurularak kategoriler oluşturulmuştur. Doküman incelemesi sonucu ortaya çıkan veriler, ilk olarak içerik analizi ile incelenmiş, içerik analizi sonucu elde edilen veriler ise betimsel analiz ile yorumlanmıştır. Araştırmada ele alınan gelenekler; doğum, evlenme, ölüm etrafında gelişen gelenekler, bayramlar, inanışlar, oyun-eğlence-spor, halk oyunları (dansları), giyim-kuşam, halk sanatları, zanaatları ve eşyalar, geleneksel halk mimarisi, geleneksel halk mutfağı, misafirperverlik, dinî kuruluşlar ve yardımlaşma-dayanışma, halk hekimliği, gurbet ve askerlik gelenekleridir.

\section{Yöntem}

\section{Araştırmanın deseni}

$\mathrm{Bu}$ araştırma, nitel bir araştırma desenlerinden durum çalışması ile yapılmıştır. Nitel araştırma, gözlem, görüşme ve doküman analizi gibi nitel veri toplama yöntemlerinin kullanıldı̆̆ı, algıların ve olayların doğal ortamda gerçekçi ve bütüncül bir biçimde ortaya konmasına yönelik nitel bir sürecin izlendiği araştırma olarak tanımlanabilir (Yıldırım, Şimşek, 2016, 41). Durum çalışması ise nicel veya nitel yaklaşımla yapılabilen, her iki yaklaşımda da amacın belirli bir duruma ilişkin sonuçlar ortaya koymak olduğu bir araştırma desenidir. Nitel durum çalışmasının en temel özelliği bir ya da birkaç durumun derinliğine araştırılması (Yıldırım, Şimşek, 2016, 73) olduğu için bu araştırmada tercih edilmiştir.

\section{Veri toplama aracı ve verilerin analizi}

$\mathrm{Bu}$ araştırmada Mustafa Kutlu'nun 2000 sonrasında yayımlanan 20 hikâyesi nitel araştırma yöntemlerinden doküman taraması ile incelenmiştir. Nitel araştırmada en çok kullanılan veri toplama yöntemleri, gözlem, görüşme ve doküman incelemesidir. Nitel araştırmada toplanan veriler nicel araştırmada olduğu gibi sayllara indirgenemez. Her ne kadar nitel yöntemlerle toplanan veriler üzerinde bazı sayısal analizler yapmak mümkün ise de, nitel araştırmada temel amaç sayılar yoluyla

\footnotetext{
\begin{tabular}{r|l} 
Adres & $\begin{array}{l}\text { Address } \\
\text { İstanbul Medeniyet Üniversitesi, Eğitim Bilimleri Fakültesi, Türkçe }\end{array}$ \\
İstanbul Medeniyet University, Faculty of Education Sciences,
\end{tabular} ve Sosyal Bilimler Eğitimi Bölümü, Türkçe Eğitimi ABD Cevizli $\quad$ Turkish and Social Scinces Education, Turkish Language Teaching Kampüsü, Kartal-İstanbul/TÜRKIYE Education, Cevizli Campus, Kartal-İstanbul /TURKEY e-posta: editor@rumelide.com $\mid$ e-mail: editor@rumelide.com
} 
sonuçlara ulaşmak değildir. Asıl amaç, araştırılan konu ile ilgili okuyucuya betimsel ve gerçekçi bir resim sunmaktır (Yıldırım, Şimşek, 2016, 48). Araştırmacı, araştırmasına başlamadan önce, alandaki kuramlardan yola çıkarak veya kendi geliştirdiği kategoriler yoluyla işe başlayabilir. Bu durumda, kategoriler önceden oluşturulmuştur ve araştırmanın amacını yansıtmaktadır (Yıldırım, Şimşek, 2017, 198). Buradan da yola çıkılarak dokümanları analiz ederken kullanılacak kategoriler, araştırmaya başlamadan önce oluşturulmuştur. Mustafa Kutlu'nun 2000 sonrası hikâyelerinde geleneksel unsurların belirlenmesi ve sınıflandırılması için Sedat Veyis Örnek'in (2018) "Türk Halkbilimi” ve Pertev Naili Boratav'ın (2016) "10o Soruda Türk Folkloru” adlı eserlerindeki tasnifler de göz önünde bulundurularak kategoriler oluşturulmuştur. Doküman incelemesi sonucu ortaya çıkan veriler, ilk olarak içerik analizi ile incelenmiş, içerik analizi sonucu elde edilen veriler ise betimsel analiz ile yorumlanmıştır.

\section{Bulgular}

\section{Doğum}

Mustafa Kutlu'nun incelenen eserlerinde doğum ile ilgili geleneksel unsurlar yer almaktadır. Çocuk sahibi olmanın Türk geleneklerinde önemli bir yer teşkil ettiği, çocuk sahibi olamayanların çocuk sahibi olmak için türlü çareler aradığı eserlerde yer almaktadır. Türk geleneklerinde çocuğa konulan ad önemlidir. Çocuğa dedenin adını koymanın yanında birden fazla kız çocuğu sahibi olan aileler erkek çocuğu olmasını istediği için doğan son kıza Songül, Yeter gibi isimleri verme geleneğini yaşatırken; çocuğunu daha önceden kaybeden aileler doğan son çocuğu ölmesin diye Duran, Dursun, Durmuş, Yaşar gibi isimler verirler. Mustafa Kutlu'nun eserlerinde geleneksel isim verme örneklerine rastlanmaktadır.

Saliha bir de beni kısır sanacaklar diye dertleniyordu. Köyde çocuk, bilhassa oğlan çocuğu çok kıymetli idi. Oğlan doğuran gelinler kasım kasım kasılıyordu. (TKS, s. 38)

Kırsal muhitte bilirsiniz çocuk çok önemli. Bir yıl, tiki yıl derken sürmeli gelinin bir türlü çocuğu olmuyor. Bilal'in başı yerden kalkmıyor. Doktorlar, hocalar kâr etmiyor. (MK, s. 118)

Bunun dedesi Ali Efendi hacca giderken kendisi doğuvermiş. Adını dedesine nisbeten Hacı Ali koymuşlar. (BÖ, s. 23)

Bir çocuk, iki çocuk, üç çocuk. Çocuklar yaşamıyor. Dördüncü hikmet-i Hüda işte ölmemiş. Adını hâliyle Duran koymuşlar. (RP, s. 13)

Dilber de sevmişti bu ismi. Çocuğun kulağına ezanı Hacı Hanım’ın eşi Hacı Bey okudu. (N, s. 62)

Türk geleneklerinde çocuğa konulan ad önemlidir. Çocuğa dedenin adını koymanın yanında birden fazla kız çocuğu sahibi olan aileler erkek çocuğu olmasını istediği için doğan son kıza Songül, Yeter gibi isimleri verme geleneğini yaşatırken; çocuğunu daha önceden kaybeden aileler doğan son çocuğu ölmesin diye Duran, Dursun, Durmuş, Yaşar gibi isimler verirler. Mustafa Kutlu'nun eserlerinde bu isimlerden Songül ve Duran isimlerinin geleneğe bağlı olarak çocuklara verildiği görülmektedir. Çocuğa ad koyacak anne babaların, kendi baba adlarını koyması ya da koymak istemesi de incelenen eserlerde tespit edilmiştir. Bunun dışında, incelenen eserlerde isim verilirken çocukların kulağına ezan okunması geleneği de görülmektedir.

\section{Evlenme}

Türk milletinin evliliğe verdiği önem nedeniyle evlenme öncesinde, evlenme anında ve evlenme sonrasında birçok geleneği vardır. Evlilik öncesinde kısmet bulma, kız bakma, annelerin çocuklarının

\footnotetext{
Adres Address

İstanbul Medeniyet Üniversitesi, Eğitim Bilimleri Fakültesi, Türkçe $\quad$ İstanbul Medeniyet University, Faculty of Education Sciences, ve Sosyal Bilimler Eğitimi Bölümü, Türkçe Eğitimi ABD Cevizli Turkish and Social Scinces Education, Turkish Language Teaching Kampüsü, Kartal-İstanbul/TÜRKIYE Education, Cevizli Campus, Kartal-İstanbul /TURKEY e-posta: editor@rumelide.com $\mid$ e-mail: editor@rumelide.com
} 
evlenecek kısmetler bulması için dua etmesi, kızların yuvaları için hazırladığı çeyiz, evlenecek çiftlerin ailelerinin tanışması, kız isteme, söz, nişan; evlilik döneminde kına, düğün ve evlilik sonrasında büyüklerin elini öpmeye gitme gelenekleri evlilik süreci ile ilgili ritüelleri zenginleştirmektedir. Mustafa Kutlu'nun incelenen eserlerinde en çok rastlanılan geleneklerden biri de evlilik ile ilgili geleneklerdir.

Harmanı savurduk, buğdayı pazara indirip sattık. Eh gücümüz yettiğince masrafını görüp kızın düğ̈̈nünü yaptık. (BÖ, s. 49)

Hadi bunu bir yana koyalım, iyice serpilip güzelleşen Nezaket'i istemeye hemen her gün birileri geliyordu. (SBÖT, s. 36)

Şimdi sen bir yandan, ben bir yandan şöyle helal süt emmiş akça-pakça bir kız arayalım. (HEG, s. 91)

Hayırlı iş bekletmeye gelmez. Gidip kızı Çolak Hüseyin'den istediler. (TKS, s. 81)

Bu sebeple Gülhanım yaylalarda istediği kızı bulamadı. Mecbur düze indi. Neyse ki vaktiyle tanıdığı bir hatunun tavsiyesi ile Cemile'yi buldu. (TKS, s. 120)

Usulüne göre üçüncü ziyarette kız isteme oldu, söz kesildi, nişan günü belirlendi. (SB, s. 79)

Mustafa Kutlu'nun incelenen eserlerinde evlilik öncesinde kısmet bulma, kız bakma ile ilgili olarak genellikle üçüncü bir şahsın aracılık yaptığı görülmektedir. Mustafa Kutlu'nun eserlerinde genellikle üçüncü şahıslar sayesinde gençler tanışmaktadır. Bunun nedeni, özellikle geleneksel hayatın hüküm sürdüğü yerlerde utanma duygusunun olması ve aksi bir durumun Türk kültürüne uygun düşmemesi olabilir. Annelerin de ölmeden önce çocuklarının mürüvvetini görmek istemesi bu kısmet bulma sürecini incelenen eserlerde hızlandırmaktadır.

Kutlu'nun eserlerinde evlenme geleneğinin gerçekleştirilmesi için ailelerin yanı sıra mahalleli ve esnaf da yine sorumluluk sahibidir. Küçüklüklerinden itibaren mahalleli/köylü tarafından tanınan kız ve erkek, yetişkin yaşa geldiklerinde o muhittekiler tarafından birbirlerine yakıştırılmaya, uygun görülmeye başlanır.

Söz ve nişan evlilik öncesi atılmış iki büyük adımdır. Bu iki önemli gelenek Mustafa Kutlu’nun incelenen pek çok eserinde karşımıza çıkmaktadır. Evlilik öncesinde yer alan bu iki döneme Mustafa Kutlu eserlerinde vurgu yapmış, Türk geleneklerini yansıtmasına dikkat etmiş, sözlülük, nişanlılık dönemine geçerken ailelerin de evliliğe razı olması gerektiği mesajı okuyucuya verilmiştir.

\section{3. Ölüm}

İslam dini ve türlü inançlar sonucu Türk geleneklerinde ölüm, insan hayatı için önemli bir geçiş dönemidir. Mustafa Kutlu’nun eserlerinde bu geçiş dönemi sıklıkla işlenmiştir.

Dedem ölünce vasiyeti gereği çiftlikteki mezarlığa defnedilmiş. (HB, s. 58)

Gelinleri teli-duvağı ile bu pınarın başına defnediyorlar. (MK, s. 10)

Bir gece sabaha doğru ruhunu teslim etti. Gün doğana kadar başucunda okudum. (MM, s. 156)

Nimet'le Cesur ara sıra mezarına gider, ruhuna Fatiha okurlar. Zaten ilk kazandıkları parayla helva kotarıp Bacı'nın helvasını bütün pazara dağıtmışlardı.

(RP, s. 158)

O yaz babaanne vefat etti. Babasiyla ara sira ve bilhassa bayramlarda ziyaret edip kabri yanına defnedildi. (SB, s. 17)

\footnotetext{
Adres Address

İstanbul Medeniyet Üniversitesi, Eğitim Bilimleri Fakültesi, Türkçe İstanbul Medeniyet University, Faculty of Education Sciences, ve Sosyal Bilimler Eğitimi Bölümü, Türkce Eğitimi ABD Cevizli Turkish and Social Scinces Education, Turkish Language Teaching Kampüsü, Kartal-İstanbul/TÜRKIYE Education, Cevizli Campus, Kartal-İstanbul /TURKEY e-posta: editor@rumelide.com $\mid$ e-mail: editor@rumelide.com
} 
Dayanamayıp Mezarcı Resul'e bir güzel mezar taşı numunesi çizip vermiş. Ben gidip taşı gördüm. Osman'ın adı altında bir gül goncası kanayıp duruyordu. (UH, s. 70)

Ölüm öncesinde ölen insanların genellikle son dileklerinin yerine getirilmesi için verdiği vasiyetin yerine getirilmesine önem verilmektedir. Vasiyet üzerine istediği mezarlığa defnedilme, kalan malımülkü bağışlama, hayır yapma gibi istekleri ölenin yakınlarınca yerine getirilmeye çalışılmaktadır. Mustafa Kutlu'nun incelenen eserlerinde de çok olmamakla birlikte vasiyet bırakma geleneğine rastlanılmaktadır. Ölüm sırasında öleceğini hisseden kişinin İslam dini gereği helallik istemesi, ölen kahramanların eserlerde genellikle huzur içinde ve yüzlerinde tebessümle ölmesi, ölenin yakınlarının cenazeye katılmalarının çok önemli olduğu, "gömmek" kelimesi yerine ise "defnetmek" kelimesinin kullanılması Mustafa Kutlu'nun eserlerinde karşımıza çıkmaktadır. Yakınını kaybeden bir insanın hemen düğün yapmasının doğru olmadı̆̆ı, ölümden sonra mezarların ziyaret edilmesi gerektiği, ölenlerin yakınlarına başsağlığı dileme geleneği, mezar taşlarının İslam dini gereği çok dikkat çekici olmak yerine sade olması ve bizim mimarimizi yansıtması gerektiği Mustafa Kutlu'nun incelenen eserlerinde yer almaktadır.

\section{Bayramlar}

Bayramlar, bir milletin arasındaki bă̆ı kuvvetlendirmede, dinî açıdan bakıldığında aynı inanç etrafında birleşen millet fertlerine aynı duyguları yaşatmada önemli olan geleneksel değerlerimizdendir. Mustafa Kutlu'nun incelenen eserlerinde Kurban Bayramı ve Ramazan Bayramı adı açıkça kullanılmamakta, bunların yerine sadece "bayram" kelimesi kullanılmaktadır. Mustafa Kutlu'nun incelenen eserlerinde dinî bayramların öneminden ve toplumdaki yerinden yeteri kadar bahsedilmemektedir.

Bu evi biliyorum. Bayram ziyaretine gelmiştik. (C, s. 70)

Ananla biz yol gözleriz, bayramdan bayrama görüşürüz, yazları bekleriz. (HG, s. 51)

Fark etmez. Mevsimler unutulmuştur artık. Gündönümü, koç katımı, bağbozumu, kırlangıç fırtınası, karakış, zemheri, hıdrellez ile çiğdemin çıkması veya günlerin uzayıp kısalması fark etmez. (BÖ, s. 204)

\section{5. İnanışlar}

Mustafa Kutlu'nun incelenen eserlerinde cansız varlıklarla ilgili inanışlar; renkler ve sayılar ile ilgili inanışlar; dinî inanışlar, nazar ve nazarlık, yatır ve ziyaret yerleri ile ilgili inanışlara yer verilmiştir.

Alnındaki kara leke yeniden peyda oldu. (KA, s. 103)

Sanki geceden biri çıkıp gelerek onun kara bahtını aydınlatacak. (İÖ, s. 45)

Turan dersen, bir zaman kendine gelememiş. "Ustanın kırkı çıkmadan fırçayı elime alamam" diyormuş ya; desin. (UH, s. 70)

Şu Hanımeli’ni yedi düvele tanıtalım. (C, s. 152)

Kurk ylllı ahbap gibi lafa girdi. (ZYH, s. 82)

Düğün kırk gün kırk gece olmasa bile üç gün üç gece sürdü. (TKS, s. 32)

Dinî inanışlar, geleneksel ögelerin şekillenmesinde önemli bir yere sahiptir. Güçlü bir inanca sahip olan Türk milleti, dini inanç etrafında geliştirdiği geleneklere sıkı sıkıya bağlıdır. Hikâyecilik anlayışını Şark-İslam kültürü ile besleyen Mustafa Kutlu, eserlerinde dinî inanışlara çok sık yer vermiştir. Hikâyelerinde gelenek ile dinî inanç çoğu zaman iç içe geçmiştir. Bu iç içe geçmiş olan gelenek ve dinî

\footnotetext{
\begin{tabular}{r|l} 
Adres & $\begin{array}{l}\text { Address } \\
\text { İstanbul Medeniyet Üniversitesi, Eğitim Bilimleri Fakültesi, Türkçe }\end{array}$ \\
İstanbul Medeniyet University, Faculty of Education Sciences,
\end{tabular} ve Sosyal Bilimler Eğitimi Bölümü, Türkçe Eğitimi ABD Cevizli $\quad$ Turkish and Social Scinces Education, Turkish Language Teaching Kampüsü, Kartal-İstanbul/TÜRKIYE $\quad$ Education, Cevizli Campus, Kartal-İstanbul /TURKEY e-posta: editor@rumelide.com $\mid$ e-mail: editor@rumelide.com
} 
inanışları modernizmin karşısına koyup millî kimliğini koruyan/korumaya çalışan kahramanlar yaratmıştır. Namaz kılmak, oruç tutmak, zekât vermek, Hacca gitmek, kurban kesmek, Kur'an okumak, tövbe etmek kahramanların dinî inançlarını yaşama yolu olarak eserlerde geçmektedir. Eserlerinde kahramanlar ezan sesi ile maddi dünyadan uzaklaşmakta, hakikate yönelmektedir. Dinî inanışlar, Mustafa Kutlu'nun incelenen eserlerinde sıklıkla geçmektedir. İncelenen eserleri içinde ise Nur (2014), Hesap Günü (2015) ve Sevincini Bulmak (2018) eserlerinde dinî inanışlar yoğunluk göstermektedir.

\footnotetext{
"Hey kurban olduğum Allah, bu defa olmazı oldur bize, sana sığınmışam" diye duaya çöktü ağa. (MK, s. 165)

Hac yolculuğu böyle olur işte. Az sonra 'Lebbeyk" demeye başlayacağız. İkimizin de kalbi kabardı, gözleri yaşardı. (MM, s. 97)

Elini alnına vurarak "Uy anaa!.. Hızır uğradı evimize de ben bir dilek dilemedim. Yazık bana, vah bana.” (HG, s. 74)

Enver’in babası daha okula gitmeden çocuğa Kur'an okumasını öğretmiş. Cuma namazlarına, teravihlerine birlikte gidiyorlar. (HEG, s. 14)

Şu hastaneden çıkayım, biraz kendime geleyim. İlk iş hacca gitmek. (N, s. 121)

İlkokulu bitirdiğimizde ikimiz de Kuran okumayı öğrenmiştik. Ayrıca Kandil gecelerinde mutlaka mahalle mescidine gider; Ramazan gelince hepimiz oruca başlardık. (SB, s. 84)
}

Mustafa Kutlu'nun incelenen eserlerinde nazar boncuğu birkaç yerde geçse de nazarın İslam dini ile ilişkili olduğu, dualarla nazardan korunmak gerektiği okuyucuya yansıtılmaktadır.

Senin bu çakır gözlerinden bir ziyan gelmez inşallah, nazar diye bir şey var ya hani. (BÖ, s. 126)

Murat anahtarı alıp nazarlığı doktora gösteriyor: Doktor Bey’le “nazar” üzerine konuşuyorduk. Ben inanırım bilirsin, doktor da inanıyor. (MK, s. 158)

Kız büyüdü, serpildi. Büyüdükçe güzelleşti. Hepimiz üzerine titriyoruz. Anam sabah akşam nazar duaları okuyor. (N, s. 34)

Çocuğun saçlarına, omuzlarına, kundağına, beşiğine nazar boncukları takıyorlardı. (TKS, s. 38)

Mustafa Kutlu ise İslâm dininde Allah'tan başkasından medet ummanın doğru olmaması nedeniyle yatır ve ziyaret yerlerden yardım isteyen kişileri incelenen eserlerinden biri olan Mavi Kuş (2002) adlı eserinde eleştirmiştir.

Çınarlar o devirden kalma. Gel zaman git zaman fidanlıktan çıkıp bayağı ağaç olan bu çınarlara çulçaput bağlamaya çabalayan saçı uzun aklı kıt kadınlar yüzünden neredeyse Çifte Gelinler Türbesi olacak iken, Osmanlı'nın feraseti, celadeti yerinde bir müftüsü 'Zinhar bağlamayasuz. Batıldır ve de dinde yeri yoktur. Yanılıp da bağlayanı tutar isem gideceği yer kanlı kütüktür." diye sıkı tembihatta bulunduğundan ağaçlar âdemoğlunun nisa taifesinden yakayı zor sıyırıyor. (MK, s. 10)

İncelenen Mustafa Kutlu eserleri içerisinde, canlı varlıklarla ilgili inanışlara sadece Uzun Hikâye (2000) adlı eserde rastlanmıştır. Bunun dışında başka hiçbir eserde canlı varlıklar ile ilgili inanışlar yer almamaktadır. Bunun nedeni, bu inanışlarda İslam dinine uygun olmayan bir anlayışın yer alması olduğu olabilir.

Uzak dağ köylerinden dağ gibi adamlar, yanık yüzlü, dik dik yürüyen kadınlar oraya huylu gelinleri, saralı çocukları falan getirir, bir horoz keser, hastayı bir gece o harabenin kuytusunda yatırırlardı. (UH, s. 26) 


\section{Oyun-eğlence-spor}

Toplumun bir ihtiyacı da oyun ve eğlencedir. Oyun ve eğlenceler de bir toplumun geleneğinden, kimliğinden izler taşır. Mustafa Kutlu'nun incelenen eserlerinde büyüklerin oyunlarında ve eğlencelerinde kahve kültürünün izleri görülmektedir. Tavla, briç, altı kol iskambil, okey, prafa, maça kızı, at yarışları, bilardo Mustafa Kutlu'nun incelenen eserlerinde öne çıkan oyunlardır. Bunun nedeni Mustafa Kutlu'nun kahve kültürünü yakından tanıan bir yazar olması ve kahvede oynanan oyunları iyi bilmesi olabilir.

Çardaklı kahvede prafa, altı kol iskambil gibi köylü oyunları oynanırken, Sefa'nın yeşil çuha kaplı masalarında briç oynayana bile rastlanır. (MK, s. 16)

Fikri Süzer'in tavla partileri. Çardaklı Kahve'de olimpiyat oyunlarından fazla ilgi çeker, müşteri toplar. Her bir oyun değme komedyenlerin sahne performansına taş çıkarır. (TÖ, s. 108)

Okey masası, bağıra çağıra maça kızı oynayanlar, gazeteye dalmış görünenler, kimsenin ona baktığı yok. (MM, s. 51)

Mustafa Kutlu'nun incelenen eserlerinde, uzuneşek, ip çekmece, salıncağa binme, saklambaç, misket, lastik top ile top oynama, ip atlama, topaç döndürme ve uçurtma uçurma geleneksel çocuk oyunlarına rastlanmıştır.

Çocuklar artık topaç çevirmiyordu. Bu oyuncak geçmişte kalmış ve unutulmuştu. Ama şimdi işe yarayacaktı işte. (HG, S. 24)

Sadullah kısa sürede mahallede arkadaş edindi. Misket oynamayı, topaç çevirmeyi, saklambacı öğrendi. (TBK, s. 85)

Çocuklar yarıyıl tatilinde evlerinin yanındaki yokuştan aşağıya doğru kızakları ile bağıra çağıra kayıyorlardı. (İÖ, s. 108)

Geleneksel sporumuz olarak kabul edilen güreş, Mustafa Kutlu'nun incelenen eserlerinde en çok rastlanan geleneksel spordur. Yiğitlik, güçlülük betimlemesi yapılan kahramanın güreş sporuyla ilgilendiği görülmektedir. Eserlerde yiğit, güçlü kişinin güreş sporuyla ilgilenmesiyle de Türk milletinin yiğit ve güçlü olduğu mesajının verildiği görülmüştür.

Sadece Pelvan Sülüman'ın güreşe çıkarken koluna bağladığı hamaylı almış hatıra olsun diye. (UH, s. 13)

Geleneksel karakucak güreşleri yapıldı. (KA, s. 153)

Yiğit adam imiş. Cafer pehlivan. Deligöz derlermiş. (HEG, s. 56)

20 hikâyeye bakıldığında geleneksel sporlar Mustafa Kutlu'nun bu eserlerinde oldukça az yer almaktadır. Bunun nedeni ise eğlence ve spora fazla ilgi duyularak dünya hayatındaki eğlencelere dalınmaması düşüncesinin okuyucuya yansıtılmak istenmesi olabilir.

\section{Halk oyunları(dansları), geleneksel çalgılar ve müzik}

Türkiye’nin yedi bölgesinden yedi ayrı renk olarak bir gökkuşağı oluşturan halk oyunları, geleneksel unsurlardan bir diğeridir. Halk oyunlarının hepsine dışarıdan bakıldığında "Türk” kimliği yansımıştır. Mustafa Kutlu'nun incelenen eserlerinde bu bağlamda halaya, Elazı̆̆’ı çayda çırasına, miskete ve çiftetelliye rastlanmaktadır.

Halk oyunlarına düşkün, nerde bir davul-zurna sesi duysa hemen mendili çekip halayın başına geçerdi. (TÖ, s. 19)

\footnotetext{
Adres | Address

İstanbul Medeniyet Üniversitesi, Eğitim Bilimleri Fakültesi, Türkçe İstanbul Medeniyet University, Faculty of Education Sciences, ve Sosyal Bilimler Eğitimi Bölümü, Türkce Eğitimi ABD Cevizli Turkish and Social Scinces Education, Turkish Language Teaching Kampüsü, Kartal-İstanbul/TÜRKIYE Education, Cevizli Campus, Kartal-İstanbul /TURKEY e-posta: editor@rumelide.com $\mid$ e-mail: editor@rumelide.com
} 
Karaltının elinde bir mum, bir de müzik sesi, galiba Elazığ'ın Çayda Çıra havası. (ZYH, s. 118)

Aslan bu defa kıralından bir misket tutturdu. Birkaç dakikada kalabalık havaya uydu, karşılıklı göbek atmaya başladı. (SBÖT, s. 128)

Gençler kâh karşılıklı oynuyor, kâh halay çekiyor. (TKS, s. 158)

Eserlerde elde edilen başka bir bulgu ise Halk Eğitim Merkezleri bünyesinde oluşturulan halk oyunu ekipleridir. Buradan yola çıkarak söylenebilir ki Mustafa Kutlu, halk oyunlarının oynanmasının yaygınlaştırılmasına önem vermektedir.

Eskiden olsaydı davul-zurna ile karşılardık; kurbanlar kesilir, azim ziyafet olurdu. (BÖ, s. 181)

Sesi güzelmiş, biraz bağlama çalıyor. (RP, s. 129)

Kendisine sorulsa söylemez ama biz biraz ud çaldığını biliyoruz. (MM, s. 8)

Adamın arkadaşları adam gibi müzisyen. Bir anda klarnet, keman ve darbuka devreye giriyor. Meydanı oynak bir hava dolduruyor. (HB, s. 14)

Cengiz Roman'dı ve iyi klarnet çalardı. (ZYH, s. 180)

Neşeli bir oğlan kanun çalıyor. (SBÖT, s. 70)

Derken kemanlar feryat etmeye, kanun inlemeye başlıyor ve tavandan bir hilale oturmuş ağır ağır inen Semiramis görünüyor. (TBK, s. 42)

Davul-zurnaya Mustafa Kutlu'nun eserlerinde coşkuyu dile getirmek için yer verilmiştir. Bunun yanında incelenen eserlerde özellikle dertli kahramanlar keman, bağlama tanbur özellikle ut çalmakta, musiki ile dertlerini paylaşmaktadır. Klarnet, ritim saz, kemençe, kanun ve darbuka incelenen eserlerde rastlanan diğer çalgı aletleridir. İncelenen eserlerde karşılaşlan bir başka gelenek ise, âşıklık geleneğidir ki Rüzgârlı Pazar adlı hikâyede aşığa saygı göstermeyen insanlar eleştirilmiştir. Ney ise tasavvuf sonucu Türk geleneklerine girmiş olup Kutlu'nun incelenen eserlerinde karşımıza çımaktadır. Halk oyunlarında olduğu gibi Halk Eğitim Merkezleri’nde eğitim alma müzik aletleri konusunda da görev üstlenmiştir. İncelenen eserlerdeki kahramanlardan bazıları Halk Eğitim Merkezi'nde bir müzik aleti çalmayı öğrenmiş ya da koroya katılmıştır. Mustafa Kutlu'nun incelenen eserlerinde yer alan davul-zurna hariç diğer müzik aletleri eğlence amacından ziyade ya para kazanmak ya da dert anlatmak için kahramanla bütünleştirilmiştir.

\section{Giyim}

Giyim-kuşam bir milletin geleneğini ve dışarıdan ilk bakışta kimliğini yansıtan bir özelliğidir. Anadolu'da yaşayan bir kadının giyim-kuşamına bakıldığında geleneksel el sanatlarından ve inançlarından doğan bir görüntü ile karşılaşılmaktadır.

İçinden annemin soluk pembe mantosu, başörtüsü, yıpranmış kunduraları, aynası ve tarağı, yüzüğü, küpeleri çıtı. (UH, s. 29)

Geleneğin muhafazası başka bir şey. Mesela Doğu Anadolu'da kadınlar incecik eğirdikleri yünden ehram dokur ve onu örterler. Dinin örtünme emrini bu geleneğin içinde sürdürürler. (HB, s. 53)

Mesela örtünme. İstanbul, Rumeli çarşaf, ferace giyinir; Erzurum, Bayburt ehram kullanır. (AY, s. 128)

Eli ayağı titreyerek, başındaki fötr şapkayı ve gözlüklerini düşürmemeye çalışarak, her adımda özürler dileyerek merdivenleri inmeye başladı. (SBÖT, s. 123)

Bu bir şaşkın köylü. Kasketli, şalvarlı, göbekli. (AY, s. 95)

Adres

İstanbul Medeniyet Üniversitesi, Eğitim Bilimleri Fakültesi, Türkce ve Sosyal Bilimler Eğitimi Bölümü, Türkçe Eğitimi ABD Cevizli Kampüsü, Kartal-İstanbul/TÜRKIYY e-posta: editor@rumelide.com 
Mustafa Kutlu'nun incelenen eserlerinde ise modernizme karşı geleneği savunan kahramanlar genellikle geleneksel giyim-kuşamla karşımıza çıkmaktadır. Bu kahramanlar yaşayış tarzlarına uygun bir giyim-kuşam benimsemişlerdir. Kutlu, modern dünyaya ayak uydurmuş kahramanlarını ise geleneksel giyim-kuşam içerisinde anlatmamaktadır. Erkek giyiminin seçilen yaşam tarzı ve meslek doğrultusunda şekillendiği Mustafa Kutlu'nun incelenen eserlerinde görülmüştür. Şalvar, keten gömlek, pardösü, kasket, lastik ayakkabı geleneksel olduğu gibi Kutlu'nun kahramanlarının meslekleri icabı tercih ettiği bir giyim-kuşam tarzıdır.

\section{Halk sanatları, zanaatlar ve eşyalar}

Türk kültüründe üretken bir insan olmak önemlidir. Her çocuk, yetişkinliğe geçerken bilgi ve yeteneğine uygun bir meslek seçmeye yönlendirilmektedir. Geleneksel anlamda bu durum usta-çırak, baba-oğul ilişkisi çerçevesinde süregelmiştir. Bu anlayış, Kutlu'nun incelenen eserlerinde de ele alınmıştır. Geleneksel meslekler dışında tüm dünyada kabul gören mesleklere incelenen eserlerde yer verilse de Kutlu, geleneksel meslekleri daha önde tutarak onlardan övgü ile bahsetmektedir.

Babadan oğula ya da ustadan çırağa geçen zanaatlar bir altın bilezik olarak anlatılmıştır. Tufandan Önce (2003) adlı eserde babadan oğula geçen aktarlık yine Tahir Sami Bey’in Özel Hayatı (2009) adlı eserde babadan oğula geçen ciltçilik anlatılmaktadır. Bunun yanında vefat etmek üzere olan ustanın dükkânını çırağına bırakması da Mustafa Kutlu'nun incelenen eserlerinde rastlanan bir durumdur. Küçük kasabalarda ise, bu meslek sahibi insanlarının birbirini iyi tanıdığı, sıcak bir ortamda mesleklerini sürdürdüklerinden bahsedilmiştir. Kahramanların meslekleri, giyim-kuşamlarına kadar onlarla bütünleşmiş bir şekilde incelenen eserlerde yer almaktadır.

Musa Çavuş matbaacılığı askerde öğrenmiş. (UH, s. 80)

Oğlanı kendi değirmenlerinden birine yerleştiriyor, değirmencilik de bir meslek elbette. (MK, s. 189)

Kasabanın en eski ailelerinden birine mensup olup, baba mesleği aktarlı̆̆ı sürdürürmüş. (TÖ, s. 141)

Fevkalade zengin bir ahşap arastası olup; bu çarşıda tuhafiye, zücaciye, demirci, bakırcı, saraç, semerci, marangoz, kalaycı, attar, terzi ve benzeri hemen bütün ihtiyaçları karşılayan dükkânları vardır. (TSBÖH, s. 37)

Ziya Usta oğlunun her ne kadar okumasını istiyorsa da, hani ne olur ne olmaz, dünya hâli bu, bu arada baba mesleği ciltçiliği de öğrenmesini istemişti. (TSBÖH, s. 67)

Bu ailenin bir mesleği taşçılık, ötekisi tespihçilik. (N, s. 186)

Bir kundura tamircisi var. Pasajın en eskisi. (SB, s. 15)

Türk geleneklerinin sanatsal yönlerinden birini oluşturan halk sanatları, Mustafa Kutlu'nun incelenen eserlerinde dokumacılık, tezhip, hat, ebru, edirnekâri, nakış, çini ve mücevherat tasarımı şeklinde karşımıza çıkmaktadır.

Bu iş öldü be hanımım. Kimse dönüp bakmıyor. Dokumacılardan -güldü biraz- biz

ikimiz kaldık. (SBÖT, s. 27)

-Edirnekari diye bir sanat vardır, bilir misiniz? Bir nevi ahşap boyama.

-Yoo, bilmiyorum.

-Küçük ahşap kutular, mücevher için, hatıra için. Sonra kahve-çay tepsileri, fotoğraf çerçeveleri. Bunları özel bir boya ile özel motiflerle süslüyorlar. Aynı şey çömlekler için de geçerli. Testi, tabak, tabla, güveç. Biliyorsunuz bizim Killîkaya köylüleri hâlâ testi, çanak, güveç yapar. Onlardan alıp boyayacağız. (SBÖT, s. 87)

Adres

İstanbul Medeniyet Üniversitesi, Eğitim Bilimleri Fakültesi, Türkce ve Sosyal Bilimler Eğitimi Bölümü, Türkçe Eğitimi ABD Cevizli Kampüsü, Kartal-İstanbul/TÜRKIYE e-posta: editor@rumelide.com
Address

İstanbul Medeniyet University, Faculty of Education Sciences,

Turkish and Social Scinces Education, Turkish Language Teaching

Education, Cevizli Campus, Kartal-İstanbul /TURKEY

e-mail: editor@rumelide.com 
Elif güngörmüş bir sanatçı hoca hanımın atelyesinde hat-tezhib-ebru ile meşgul olmaya başladı. (SB, s. 132)

Nilgün mücevherat tasarımı yapıyor. (SB, s. 133)

Beyaz zemin üzerine mercan kırmızısı, yaprak yeşili, mavi, lacivert gibi renkler ile narçiçeği, rozetler, ince dallar, hatayiler ile çiniler harika. (SB, s. 191)

Elif kendi tezhibi ile süslediği, günümüzün önemli hattatlarından birinin eseri olan Besmele'yi hediye etti. (SB, s. 229)

Özellikle dokumacılık sanatı üzerinde Stradışı Bir Ödül Töreni (2013) adlı eserde, tezhip sanatına ise Sevincini Bulmak (2018) adlı eserde rastlamaktayız. Sevincini Bulmak adlı hikâyede geleneksel hayatı benimseyen bir kahraman olan Elif, tezhip sanatı ile ilgilenmektedir. Sevincini Bulmak (2018) adlı eserde, hattatlıktan da bahsedilmektedir. Stradışı Bir Ödül Töreni adlı eserde, dokumacıllğın eski önemini yitirmesini yazar tarafından yeri geldikçe vurgulanmıştır.

Mustafa Kutlu'nun incelenen eserlerinde eşyalar mimari ile bütünleştirilerek geleneksel görünüm tamamlanmıştır. Mustafa Kutlu'nun incelenen eserlerinde geleneksel evlerde yer alan eşya isimlerini görmek mümkündür.

Sağında solunda ustasının solgun imzasını, yapım tarihini taşıyan bakır siniler, bakır taslar, kirpikli sahanlar, yamrı-yumru olmuş karavanalar, kulpu kırık gügüumler, maşrapalar, kalayı uçmuş dibi zehir yeşiline çalan bulgur kazanları, çamaşır leğenleri, kuyu bakraçları, üsküreler, yă̆ tavaları, kepçeler... (BÖ, s. 138)

Dükkân kocaman. Silme dolu. Bulgur taşından kara sabana kadar ne ararsan var. Altın, gümüş, yakut, kehribar her tür süs eşyası, mücevher; seramikler, çiniler, eskisi yenisi, antikası, halılar, kilimler, heybeler, seccadeler, yazmalar, eski elbiseler. Saymakla bitmez. (C, s. 141)

Geçmişte çok kullanılan fakat günümüzde kullanımı azalan eşyalara ya da yeni neslin bilmediği, günümüzde kullanılmayan eşyalara eserlerde yer verilerek hatırlanması ya da bilinmesi Kutlu tarafından amaçlanmış olabilir.

\section{Halk mimarisi}

Bir şehrin ruhunu oluşturan unsur, mimarisidir. Mimariyi geleneksel yapan ise, halkın yaşam şartlarına ve inançlarına uygun şekilde yapılmıș olmasıdır. Evi bahçeli ve ahşap olup bir cephesi sokağa bakardı. (UH, s. 37)

Geniş, ferah bir mekân. Duvarlar ahşap. Duvarlarda ne bahkçı ağı, ne tablo, ne süs. Tamamen çıplak. Ölçülü bir dekorasyon. (C, s. 149)

Ciftlik evi tas bina, kim bilir hangi beyin zamanında yapılmış. O kadar büyük değil ama süslü. Pencere pervazları, kapı alınları oymal. Babam içerinin ahşap aksamın tamamen yenilemiş. Kestane, ıhlamur, çam kullanmış. İçeride hiç dinmeyen bir ahşap kokusu var. Ahşabın munis sicaklğ̆ ile taşın sert soğuğu dengeleniyor. (HB, s.161)

Erzurum'da taş ve kerpiç kullanılırken; Karadeniz'de ahşap, yapıya ayrı bir güzellik katar. Eğin evlerinde de ahşap malzeme ağırlktadır. İstanbul'da Erenköy'de, Beylerbeyi’nde, Boğaz'da gördüğ̈̈nüz kössk ve konaklarn benzerini Eğin'de görebilirsiniz. Ikki kath, üç kath. Köylerde dahi bu mimari hâkimdir. (TSBÖH, s. 38)

Doktor bir evi döşeyecek her şeyi ald. Zaten marangozlara salon için dört köşeli bir sedir yaptrrmışt. İşte bir Türk evi nasıl döşenir öyle döşediler. (ïÖ, s. 138)

Mustafa Kutlu'nun incelenen eserlerinde ahşap, kerpiç ve taşın ana malzeme olarak yer aldığı, ferah, aydınlık, az katlı, geniş, tavanı yüksek, bahçeli, yeşillikle iç içe geçmiş, dışarıdan bakıldığında bir Türk evi denilebilecek geleneksel mimari anlayıșın yer aldı ̆̆ını görmekteyiz.

\footnotetext{
İstanbul Medeniyet Üniversitesi, Eğitim Bilimleri Fakültesi, Türkçe İstanbul Medeniyet University, Faculty of Education Sciences, ve Sosyal Bilimler Ĕ̆itimi Bölümü, Türkce Ĕ̆itimi ABD Cevizli Turkish and Social Scinces Education, Turkish Language Teaching Kampüsü, Kartal-İstanbul/TÜRKIYY $\quad$ Education, Cevizli Campus, Kartal-İstanbul /TURKEY e-posta: editor@rumelide.com $\mid$ e-mail: editor@rumelide.com
} 


\section{Halk mutfağı}

Geleneksel halk mutfağını etkileyen baş unsur Anadolu'daki ekonomik geçim kaynağı olan tarım ve hayvancılıktır. Geleneksel halk mutfağımızın yiyeceklerle ilgili olan kısmında yer alan, erişte, kavurma, bulgur pilavı, tarhana, turşu, pekmez, peynir çeşitleri, yufka ekmeği, kuru fasulye, tirit, hoşaf, zerde, sütlaç, helva, reçel çeşitleri, su böreği, ev yoğurdu, yaprak sarması Mustafa Kutlu'nun incelenen eserlerindeki halk mutfağı ögelerinde de yer almaktadır. Mustafa Kutlu'nun eserlerindeki yiyecekler, geleneksel halk mutfağı içerisinde yeri olan yiyeceklerdir.

Bulguru, tarhanayı kotardık. Bir de toklu devirip kavurmayı kaynatırsak tamamdır.

(BÖ, s. 49)

Yemekler işte bildiğiniz orta malı şeyler. Ciğer yahni, kuru fasulye, pilav, kayısı hoşafı, ara sıra kızartma, lokma tatlısı vesaire. (MK, s. 14)

Kaymakam bir hoşluk olsun diye yemeğe tatlı ilave edelim teklifini getirince, bu tatlının ne olabileceği tatlı tatlı tartışılıyor. Sütlaç, zerde, tulumba, helva adları geçiyor. (TÖ, s. 58)

Sevdiğim yemekleri, mesela karnıyarık, peynirli makarna, vişne kompostosu falan ihmal etmezdi. (C, s. 36)

Kebaplara yumulduk. Kerpiç gibi ev yoğurdu, baklava, yemekten sonra el açıp uzun bir sofra duası yaptım. (MM, s. 128)

Memleketten badem, ceviz, dut kurusu, işte bir şeyler geliyor. (TSBÖH, s. 92)

Çocuklara pekmez, reçel kaynattılar. Sebze kurusu gönderdiler. Kış boyu peynir, taze tereyağı, hatta oranın ekmeğinden bile gönderdiler. (HG, s. 153)

Şurda bir miktar kesme çorba olacak bir de yarım ekmek. (İÖ, s. 9)

Güvecin yanına sade pilav, sonra su böreği, çoban salata. (SB, s. 205)

Türkler çayı sever. Yeni koymuştum, ister misiniz? (MM, s. 71)

Önce bir ayran içtiler. Oya koyun sütünden yapılan bu yayık ayranına bayıldı. (ZYH, s. 55)

Canan babasına kahve yapmıştı, Ferit ben de isterim dedi. Kahveler içilirken sohbet açıldı. (ZYH, s. 74)

Öyle ki Nezaket annesi, komşuları, mahalleden arkadaşları ile misafirlere ikramı için Osmanlı usulü gül şerbeti ve limonata bile yapmıştı. (SBÖT, s. 96)

Geleneksel yiyeceklerin yanında da sıklıkla tüketilen ayran, Türk milletinin vazgeçilmez içeceği çay, sohbetlere eşlik eden Türk kahvesi, nar ve gül ile yapılan geleneksel şerbetler, özellikle kışın tüketilen salep Mustafa Kutlu'nun incelenen eserlerinde yer almaktadır. Kutlu, eserlerinde Anadolu insanın beslenme şekline dikkati çekmiş ve halkın yeme-içme kültüründen gelmeyen yiyecek-içeceklere eserlerinde yer vermemiştir.

\section{Dayanışma, yardımlaşma ve dinî kuruluşlar}

Türk milletinin başat özelliklerinden biri olan misafirperverlik, Türk kültürünün insana verdiği değeri yansıtmaktadır. Toplumdaki insanlar arasındaki bağları artırıp, insanların birbirine duyduğu saygı ve sevgiyi tazelemektedir. Kutlu'nun incelenen eserlerinde de misafirperverlik yer almaktadır. İncelenen eserlerin bazılarında kahramanların misafiri çok sevdiği de vurgulanmıştır.

Bir kere ben kendisini, kendi hanemde misafir ettim. Allah ne verdiyse birlikte yedik içtik. (BÖ, s. 185)

Olmaz Kadir Usta. Sen artık benim misafirimsin. Misafir ev sahibinin izni olmadan şurdan şuraya adım atamaz. (MM, s. 129)

\footnotetext{
İstanbul Medeniyet University, Faculty of Education Sciences, ve Sosyal Bilimler Ĕgitimi Bolümü, Kampüsü, Kartal-İstanbul/TÜRKIYE Education, Cevizli Campus, Kartal-İstanbul /TURKEY e-posta: editor@rumelide.com 1 e-mail: editor@rumelide.com
} 
Misafiri orada ağırlar, orada yiyip içerlerdi. Doğrusu misafiri çok seviyordu. (TKS, s. 146)

Dinî kuruluşlar yardıma muhtaç insanlara kapı açmada ve onları hakikatle buluşturmada önemli roller üstlenmiş kuruluşlardır. Kutlu'nun incelenen eserlerinde tarikat ve tekkelerin varlığına rastlanmıştır. İncelenen eserlerde kahramanlar, beyaz bir sayfa açmak, modern hayattan kopup geleneksel hayata uygun bir yaşam sürmek ve en önemlisi Allah'a iyi bir kul olabilmek için tekkenin kapısına varmaktadır.

Bir iki kez anasıyla tekkeye gitti. Namaz kıldı, dua etti. (TBK, s. 48)

Seni bizim tekkeye götürürüm. Aklın kalbin razı gelirse efendiye mürid olursun. (HEG, s. 64)

Tepede Kaşgari Tekkesi var. İstanbul'da yangından yakasını kurtarmış nadir ahşap tekkelerden biri. (SB, s. 176)

İmece, genellikle kırsal yerlerde yaşayan insanların karşılıklı yardımlaşarak dayanışmasını sağlayan bir gelenektir. Mustafa Kutlu'nun incelenen eserlerinde kırsal yerleşim yerlerinde varlığını sürdüren bu imece tarla işlerine yardımda, yol yapmada, ortak alan temizliğinde karşımıza çıkmaktadır. Yardımlaşma ve dayanışma içerisinde yaşamak ise Türk milletinin önemli bir özelliğidir ve Mustafa Kutlu'nun incelenen eserlerinde örneklerine sıklıkla yer verilmiştir.

Ev halkına ilaveten komşu kadınlardan birkaçı orak işinde bize yardıma gelmişlerdi. (BÖ, s. 5)

Kazmayı küreği kapıp imece usulü ile epeyce bir zaman uğraştıktan sonra; dereler üzerine şimdilerde dahi görenleri hayranlığa sevk eden, ince kavisli, zarif köprüler inşa ederek, kağnı arabalarının, at arabalarının, yüklü develerin geçeceği yolu tamam etmişler. (KA, s. 24)

Ziya'nın dar günde lazım olur diye bir yana koyduğu para; Feride'nin aynı gerekçeyle dişinden tırnağından artırıp -ne de olsa yokluk görmüş biriydi- biriktirdiği, biriktirip aldığı bir iki Reşat altını, çarşı esnafının aralarında topladıkları yardımla düğünü yaptılar. (TSBÖH, s. 54)

Hasta için lazım olursa arabalar burada. Bir haber uçurun, hangi arkadaş olsa gelir. Biz burada bir aile gibiyiz. (ZYH, s. 21)

Ama dedik ya, adam hayır sahibi, sade bana değil pek çok talebeye yardım ediyor. (AY, s. 61)

Ah bu benim gönlü bol insanım. Yemez, yedirir, giymez giydirir. Böyle bir ahlâk işte. (TBK, s. 91)

İncelenen eserlerde, yardıma muhtaç olan insanlara yardım eden, el uzatan birileri vardır. Yardıma muhtaç olan insana yardım eden kişi bu eserlerde her zaman çok varlıklı değildir, zengin olmayan biri de yardıma ihtiyacı olan insana yardım ederken karşımıza çımmaktadır. İncelenen eserlerde yardım edilenler içerisinde yetimler olduğu da görülmektedir. Yetimlere yardım etmenin önemine de bu eserlerde dikkat çekilmiştir. Tirende Bir Keman (2015) adlı eserde ise Türk insanının gönlü bol olduğu Mustafa Kutlu tarafından dile getirilmiştir.

\section{Halk hekimliği}

Halk hekimliği, doktora gitmenin mümkün olmadığı ya da doktora gitmenin tercih edilmediği zamanlarda, hastalıklara halkın bir derman bulmasıyla ortaya çıkmıştır.

Adamotu dedikleri şey patates yumrusuna benzer; şöyle boğum boğum uzanan, griye çalar kabuklu, ormandan devşirilen bir bitki kökü. Bıçakla kesiver, özü beje yakın beyaz. Kesilen yerden süt gibi sıvı damlıyor. Kazıyorsun, kazıyorsun; kırpıntıları elinle topla, şöyle parmaklarının arasında ovala, yumuşak yumuşak. Az sonra mübarek merhem gibi oluyor. Gibisi fazla bildiğin merhem. Ağrılara birebir. (RP, s. 58)

Kolu, bacağı kırıldı. Çıkıkçıya götürdüler; çıkıkçı zor iş, inşallah tutar deyip kolu bacağı sardı. (TSBÖH, s. 56)

Adres

İstanbul Medeniyet Üniversitesi, Eğitim Bilimleri Fakültesi, Türkce ve Sosyal Bilimler Eğitimi Bölümü, Türkçe Eğitimi ABD Cevizli Kampüsü, Kartal-İstanbul/TÜRKIYE e-posta: editor@rumelide.com
Address

İstanbul Medeniyet University, Faculty of Education Sciences,

Turkish and Social Scinces Education, Turkish Language Teaching

Education, Cevizli Campus, Kartal-İstanbul /TURKEY

e-mail: editor@rumelide.com 
Köyde kundak çocuklarını ince elemiş bir toprağa yatırıyorlar, buna höllük diyorlar. Kayınvalidesi bu toprağın çocuk vücudunun ıslaklığını emdiğini, çok sağlıklı olduğunu söylüyor, böylece bezleme derdinden de kurtulduklarını ileri sürüyordu. (TKS, s. 37)

Kızılcık reçeli, kuşburnu kurusu -bundan yapılan çay üst solunum sıkıntılarına, nezle-gribe iyi gelirmiş. Biliyorum kardeşim, benim ablam Eczacı Sevim. Bitki çayları ondan sorulur-, aluç diye bir meyve. (SB, s. 288)

Mustafa Kutlu'nun incelenen eserlerinde özellikle bitkilerin hastalıklara çare olarak kullanıldığı görülmektedir. Bu bitkiler arasında adamotu, nane, limon, ıhlamur, aluç yer almaktadır. Bunun dışında çocukların sağlıklı olması için uygulanan höllük adı verilen işlemden Tarla Kuşunun Sesi (2017) adlı eserde bahsedilmiştir.

\section{Gurbet ve askerlik}

Gurbet, çeşitli nedenlerle insanın doğup büyüdüğü yerden ayrı düşmesi, uzak kalmasıdır. Bu gurbet çerçevesinde Türk kültüründe çeşitli gelenekler ortaya çımıştır. Bu geleneklerden biri gurbetten memleketine gelen insanın evine ziyarette bulunmaktır. Mustafa Kutlu'nun Beyhude Ömrüm (2001) adlı eserinde gurbetten dönenin evine yapılan ziyaretten bahsedildiği görülmektedir. Bunun dışında incelenen eserlerde gurbet ile ilgili göze çarpan bir başka durum ise gurbetçilerin gurbete giderken yanlarında köyde yapılmış olan yiyeceklerden götürmeleridir. Bunun nedeni, özellikle büyük şehre giden insanların orada yoksulluk çekmesidir. Mustafa Kutlu’ya göre yoksulluk köylerde, kasabalarda değil şehirlerdedir. Köydeki insanlar topraktan beslenir ya da komşularının yardımıyla da olsa karnını doyurur. Şehirdeki insan ise yalnızdır ve topraktan uzaktır. Mustafa Kutlu'nun incelenen eserlerinde gurbetçinin bu yalnızlı̆̆ hissettirilmektedir. İncelenen eserlerde gurbetçilerin yaz mevsiminde gelip güz mevsiminde gittiğinden bahsedilmektedir.

İstanbulcular önce "hoş geldin”e gelenleri kabul edeceklerdi. Odalarda günnük yakılıp, güzel kokular etrafı saracaktı. Haberler alınıp verilecekti. Gidişattan konuşulacaktı. Hacı Bekir şekerleri, lokumları yenilecek, belki kahve bile içilecekti. (BÖ, s. 115)

Gurbetçi, bir de ailesi ile gidiyorsa perona yükünü yığmıştır. Peynir tenekesinden, turşu küpüne, tereyağından kavurmaya, erişteden bulgura say sayabilirsen. Niçin bunca eziyet? Eh, cepte para yok. (TBK, s. 96)

Akşam olup, konu-komşu asker görmesini bitirip evlerine çekilince; biz bize kalınca, ev halkını toplayıp bir bilmece sorardım. (BÖ, s. 13)

Çoğu yerde askerliğini yapmamış delikanlıya kız vermezler. (MK, s. 183)

Delikanlılar Cihan'a asılıyor, "Oğlum yaşın geldi geçiyor, askerliği de bitirdin, tohuma kaçacaksın, bekletme zavallı Zehra'yı, istet bitsin bu iş.” diyorlar; Cihan kızarıp önüne bakıyor, ağzından tek kelime çıkmıyordu. (KA, s. 55)

Askerlik gençleri olgunlaştırır. Vatani görevini bitirip dönenler yavukluları ile evlenir. (TKS/95)

Askerlik bitti, geri döndü. Daha bir olgunlaşmış, daha bir Harun olmuş ki, aşk olsun. Askerlik böyledir, Peygamber ocağı. (SB, s. 56)

Askerlik, Türk kültüründe çok önemli bir yere sahip olup "Peygamber Ocağı” olarak görülmektedir. Askerlik çerçevesinde birçok gelenek ortaya çımıştır. Bunlardan biri askerden gelen kişinin ziyaret edilmesidir. Mustafa Kutlu'nun incelenen eserlerinde askerliğin yer aldığı görülmektedir. Beyhude Ömrüm (2001) adlı eserde komşuların askeri ziyaret ettiğinden bahsedilmektedir. Bunun yanında incelenen eserlerde askerlik ile bahsedilen başka bir durum ise askerliğini yapmayan kişiye kız verilmemesidir. İncelenen eserlerde askerliğini bitiren erkeğin sevdiğiyle evlendiğine vurgu yapılmaktadır. Türk kültüründe askere gidip gelen kişinin olgunlaştığına inanılır. Mustafa Kutlu'nun incelenen eserlerinde bu olgunlaşmadan da bahsedilmektedir. 


\section{Sonuç}

Mustafa Kutlu'nun 2000-2018 yılları arasında yayımlanan hikâyelerinde en çok yer alan gelenekler, evlenme geçiş dönemi etrafında gelişen geleneklerdir. Evlenme etrafında gelişen gelenekleri sırasıyla dinî inanışlar, ölüm geçiş dönemi etrafından gelişen gelenekler, meslekler ve halk mutfağı takip etmektedir. Toplumun değerlerine uygun olarak evlenmenin toplumdaki geleneksel evlilik algısını desteklemesi ve ailenin toplumun yapı taşlarından biri olması nedeniyle Mustafa Kutlu evliliğe önem vermiştir. Evlenme geçiş dönemi geleneklerinden sonra en çok rastlanılan gelenekler dini inanışlarıdır. Mustafa Kutlu, yetiştiği çevre ve kişiliğinin de etkisiyle İslam dinini hayatın merkezine almış bir yazardır. Eserlerinde de bu hassasiyeti hissetmek mümkündür. Dini inanışlardan sonra ise karşımıza en çok ölüm çevresinde gelişen gelenekler çlkmaktadır. Ölümün bir son olmadığına inanılan İslam dininin etkisiyle Türk kültüründe ölüm öncesinde, anında ve sonrasında çeşitli gelenekler yer almaktadır. Mustafa Kutlu da ölüm konusundaki dini ve kültürel hassasiyetini eserleri aracılığıyla yansıtmıştır. Karabıyık (2019) yaptığı çalışmada, tasavvuf kültüründe yer alan, dünyaya itibar etmemenin ve asıl olan öteki dünya için çalışmanın Mustafa Kutlu hikâyelerinin tematik arka planında yer aldığını tespit etmiştir. Mustafa Kutlu'nun eserlerindeki halk bilimi unsurlarının tespit edildiği ilk çalışmayı yapan Bolat'ın (2007) çalışmasında yer verdiği bulgulara göre de Mustafa Kutlu'nun eserleri doğum, evlenme, ölüm ile ilgili gelenekleri içinde barındırmaktadır. Bayrak Kahraman'ın(2019) Mustafa Kutlu'nun 2010-2018 yılları arasındaki hikâyelerini halk bilimi unsurları açısından incelediği çalışması, doğum, evlilik, ölüm geçiş dönemi geleneklerinin bütün eserlerde yer aldığını tespit etmesi yönüyle bu çalışmayla örtüşmektedir. Mustafa Kutlu'nun 2000-2018 yılları arasında yayımlanan hikâyelerinde en az rastlanan geleneksel unsur, canlı varlıklar ile ilgili inanışlardır. Canlı varlıklar ile ilgili inanışları sırasıyla, sünnet, nazar boncuğu, yatır ve ziyaret yerleri ile ilgili inanışlar, eğlence ve spor takip etmektedir. Mustafa Kutlu, İslam dinine uygun olmayan inanışları doğru bulmamakta, eserlerinde eleştirmektedir. Canlı varlıklar ile ilgili inanışların, nazar boncuğunun ve yatır ve ziyaretlerle ilgili inanışların bu nedenle az yer aldığı düşünülmektedir. Mustafa Kutlu'nun eserlerinde eğlence ve spora az rastlanması, Kur'an'da yer alan "Bu dünya hayatı ancak bir eğlence ve oyundan ibarettir.” ayetinin Mustafa Kutlu'da yarattığı etki ile açıklanabilir. Dünyanın eğlencesine kapılıp ahirete önem vermemeyi yanlış bulan yazar, eserlerinde bunu okuyucuya hissettirmektedir. Alan ve Çolakoğlu (2020) da yaptıkları çalışmada "Metnin özüne yerleştirdiği mesajlarla öykü türüne işlevsel bir rol yükleyen Mustafa Kutlu, anlatılarında şehirlere nispetle kültürünü daha iyi muhafaza eden kasaba ortamlarını ve buralardaki Anadolu insanını ele alır. Kurguladığı insan tipleriyle, modern hayatın koşturmacası içinde hakikati yitirmiş olanları uyandırmaya çalışır." tespitinde bulunmuşlardır. Bu tespit, çalışmamızın sonucuyla örtüşmektedir. Yapılan araştırma sonucunda, Mustafa Kutlu'nun incelenen eserlerinde geleneksel ögelerin fazlasıyla yer aldığı görülmüştür. Eserlerde yer alan gelenekler sayesinde kahramanların birbiriyle olan ilişkisi kuvvetlendirilmiştir. Kuvvetli ilişkilere sahip toplum, hangi geleneklere sahip olduğunu unutmayan, millî kimliğinin bilincinde olan toplumdur. Yalnızlaşan, geleneksel değerlerden uzaklaşan insanlar ise kendini yaşadı̆̆ topluma ait hissedemeyecek olup millî kimliğinden uzak bir yaşam sürecektir. Millî kimliğinden uzaklaşmış, geleneklerine uygun yaşamayan insanların gelecek nesilleri de millî kimliğine sahip çımayan hatta farkında olmayan bireyler olarak yetişecektir. Bu araştırmanın yapılma amacının millî kimliklerin inşasında rolü olan gelenekleri, edebî metinler aracıllğıyla bir milletin yeni nesillerine aktararak millî kimlik inşasına katkıda bulunmak olduğu düşünüldüğünde Mustafa Kutlu’nun hikâyeleri milli kimliği açısından önemli bir yere sahiptir. Bu eserler, öğretmenler tarafından öğrencilere önerilmeli ve millî kimlik inşasına küçük yaşlardan itibaren başlanmalıdır.

Adres

İstanbul Medeniyet Üniversitesi, Eğitim Bilimleri Fakültesi, Türkce ve Sosyal Bilimler Eğitimi Bölümü, Türkçe Eğitimi ABD Cevizli Kampüsü, Kartal-İstanbul/TÜRKIYE e-posta: editor@rumelide.com 


\section{Kaynakça}

Alan, S.; Çolakoğlu, D. (2020). Mustafa Kutlu'nun Uzun Hikâyesinde Öne Çıkan Değerler,Avrasya Uluslararası Araştırmalar Dergisi, S. 22, Haziran, s. 387-401.

Anar, T. (2012). Mustafa Kutlu'nun Hikâyelerinde Ezan Sesinin İşlevleri. Aynanın Sırrı: Mustafa Kutlu Sempozyum Bildirileri Kitabı. İstanbul: Küçükçekmece Belediyesi, s. 332-343.

Arıcı, A. F.; Sallabaş E.; Yorgancı, O. K. (2018). Dil Bilinci ile Millî Kimlik İlişkisi. 1. Türk Eğitim Kongresi Bildirileri. İstanbul: Ylldız Teknik Üniversitesi, s. 35-42.

Atasoy, F. (2009). Küreselleşmenin Etkisi Altında Millî Kimlikler ve Türk Kimliği. Türk Kimliği. Ayvaz Gökdemir"e Armağan-2. Editör: M. Çağatay Özdemir. İstanbul: Ötüken, s. 826-844.

Bayrak Kahraman, F. (2019). Mustafa Kutlu'nun Hikâyelerinde Halk Bilimi Unsurları (2010-2018). Yayımlanmamış yüksek lisans tezi. Ağrı İbrahim Çeçen Üniversitesi, Sosyal Bilimler Enstitüsü, Türk Dili ve Edebiyatı Anabilim Dalı.

Bolat, B. (2007). Mustafa Kutlu'nun Hikâyelerindeki Halk Edebiyatı ve Halk Bilimi Unsurlarının İncelenmesi. Yayımlanmamış yüksek lisans tezi. Selçuk Üniversitesi, Sosyal Bilimler Enstitüsü, Türk Dili ve Edebiyatı Anabilim Dalı.

Boratav, P. N.(2016). 100 Soruda Türk Folkloru. Ankara: Bilgesu.

Eflatun, M. (2019). Anadolu'da İdeal İnsan Tipi’nin Oluşumunda Kuruluş Dönemi Klasik Türk Edebiyatı Metinlerinin Katkıları. İdeal Türk: Eğitimde İdeal İnsan ve Millîlik Arayışları. Editörler: Ali Fuat Arıı, Mustafa Başaran. İstanbul: Türk Edebiyatı Vakfı, 139-150.

Güvenç, B.(2005) Türk Kimliği, Kültür Tarihinin Kaynakları. İstanbul: Remzi.

Karabıyık E. (2019). Mustafa Kutlu'nun Hikâyelerinde Tekrar Eden Konular. Yayımlanmamış yüksek lisans tezi. Kastamonu Üniversitesi, Sosyal Bilimler Enstitüsü, Türk Dili ve Edebiyatı Anabilim Dall.

Kösoğu, N. (2018). Millî Kültür ve Kimlik. İstanbul: Ötüken.

Kutlu, M. (2015). Anadolu Yakası. İstanbul: Dergâh.

Kutlu, M.(2015). Beyhude Ömrüm. İstanbul: Dergâh.

Kutlu, M. (2018). Chef. İstanbul: Dergâh.

Kutlu, M. (2019). Hayat Güzeldir. İstanbul: Dergâh.

Kutlu, M. (2018) Hesap Günü. İstanbul: Dergâh.

Kutlu, M. (2019).Huzursuz Bacak. İstanbul: Dergâh.

Kutlu, M. (2016). İyiler Ölmez. İstanbul: Dergâh.

Kutlu, M. (2019). Kapıları Açmak. İstanbul: Dergâh.

Kutlu, M. (2019). Mavi Kuş. İstanbul: Dergâh.

Kutlu, M.(2019). Menekşeli Mektup. İstanbul: Dergâh.

Kutlu, M. (2019). Nur. İstanbul: Dergâh.

Kutlu, M. (2019). Rüzgârlı Pazar. İstanbul: Dergâh.

Kutlu, M. (2018). Sevincini Bulmak. İstanbul: Dergâh.

Kutlu, M. (2018). Sıradışı Bir Ödül Töreni. İstanbul: Dergâh.

Kutlu, M. (2019).Tahir Sami Bey’in Özel Hayatı. İstanbul: Dergâh.

Kutlu, M. (2019).Tirende Bir Keman. İstanbul: Dergâh.

Kutlu, M. (2017). Tarla Kuşunun Sesi. İstanbul: Dergâh.

Kutlu, M. (2017).Tufandan Önce. İstanbul: Dergâh.

\footnotetext{
\begin{tabular}{r|l} 
Adres & $\begin{array}{l}\text { Address } \\
\text { İstanbul Medeniyet Üniversitesi, Eğitim Bilimleri Fakültesi, Türkçe }\end{array}$ \\
İstanbul Medeniyet University, Faculty of Education Sciences,
\end{tabular} ve Sosyal Bilimler Eğitimi Bölümü, Türkce Eğitimi ABD Cevizli $\quad$ Turkish and Social Scinces Education, Turkish Language Teaching Kampüsü, Kartal-İstanbul/TÜRKIYE $\quad$ Education, Cevizli Campus, Kartal-İstanbul /TURKEY e-posta: editor@rumelide.com 1 e-mail: editor@rumelide.com
} 
Kutlu, M.(2019). Uzun Hikâye. 61. bs. İstanbul: Dergâh.

Kutlu, M. (2019).Zafer Yahut Hiç. 12. bs. İstanbul: Dergâh.

Örnek, S. V. (2018). Türk HalkBilimi. Ankara: Bilgesu.

Ylldırım, A.; Şimşek, H. (2016). Sosyal Bilimlerde Nitel Araştırma Yöntemleri. 2. bs. Ankara: Seçkin. 